Research article

\title{
ISOLATION AND MOLECULAR DETECTION OF BOVINE PARAINFLUENZA VIRUS TYPE 3 IN CATTLE IN SERBIA
}

\author{
VELJOVIĆ Ljubiša ${ }^{1}$, KNEŽEVIĆ Aleksandra², MILIĆ Nenad ${ }^{3}$, KRNJAIĆ Dejan ${ }^{3}$, \\ MIKOVIĆ Radoš ; ZORIĆ Andrea ${ }^{3}$, MARKOVIĆ Maja ${ }^{3}$ MILIĆEVIĆ Vesna ${ }^{1}$, \\ STAMENKOVIĆ Miodrag ${ }^{5}$, STANOJEVIĆ Maja ${ }^{2}$, MAKSIMOVIĆ-ZORIĆ Jelena ${ }^{1}$, \\ PETROVIĆ Tamaš*6, NIŠAVIĆ Jakov ${ }^{3}$
}

${ }^{1}$ Scientific Institute of Veterinary Medicine of Serbia, Vojvode Toze 14, Belgrade, Serbia; ${ }^{2}$ Virology Department, Institute of Microbiology and Immunology, School of Medicine, University of Belgrade, Dr Subotica 8, Belgrade, Serbia; ${ }^{3}$ Department of Microbiology, Faculty of veterinary medicine University of Belgrade, Bul. Oslobođenja 18, Belgrade, Serbia; ${ }^{4}$ Specialized Veterinary Laboratory, Bul. Džordža Vašingtona, bb, Podgorica, Montenegro; ${ }^{5}$ Medicines and Medical Devices Agency of Serbia, Vojvode Stepe 458, Belgrade, Serbia, 'Virology department, Scientific Veterinary Institute „Novi Sad“, Rumenački put 20, Novi Sad, Serbia

(Received 14 February; Accepted 15 November 2016)

The presence of bovine parainfluenza virus type 3 (BPIV3) was examined in 119 nasal swabs collected from cattle with severe respiratory infection. All samples were conducted for virus isolation on the MDBK cell line. The cytopathic effect was observed after $48 \mathrm{~h}$ to $72 \mathrm{~h}$ in cells inoculated with eight samples $(8 / 119 ; 6.7 \%)$. The confirmation of isolated strains of BPIV3 was done by the virus-neutralization test. In addition, all samples of bovine nasal swabs were also examined for the presence of BPIV3 virus using RT-PCR with primers specific for the part of $\mathrm{HN}$ gene. The presence of BPIV3 was detected in eight samples $(8 / 119 ; 6.7 \%)$ that were also positive upon virus isolation. The molecular characterization based on nucleotide sequencing of the part of the HN gene showed that all BPIV3 isolates belonged to genotype C of BPIV3. They branched in one distinct cluster with three different branches, but these branches were very similar to each other $(98.1 \%$ to $99.8 \%)$. Serbian BPIV3c isolates were most similar to the Chinese BPIV3c isolates SD0805, SD0809 and SD0835 (from 97.92\% to $99.7 \%$ ), and to South Korean (12Q061), Japanese (HS9) and American (TVMDL16 and TVMDL20) BPIV3c strains (from 97.1\% to 98.8\%), and distinct from American (TVMDL15and TVMDL17) and Australian (Q5592) BPI3V genotype B strains (only $79.9 \%$ to $82.3 \%$ similarity), as well as from the genotype A BPIV3 strains from different countries published in GenBank.

Key words: bovine parainfluenza virus type 3, virus isolation, RT-PCR, Serbia

\footnotetext{
*Corresponding author: e-mail: tomy@niv.ns.ac.rs
} 


\section{INTRODUCTION}

Bovine parainfluenza virus type 3 (BPIV3) is an important pathogen of the known viruses associated with bovine respiratory disease complex (BRDC), which is a major health problem of cattle worldwide. BPIV3 is one of the most common causative agents of respiratory infection of cattle and sheep, especially in youngsters in intensive and extensive livestock production. Primary infection is usually followed by secondary bacterial infections which can lead to death. Clinical signs associated with BPIV3 infections are cough, anorexia, pyrexia, nasal and ocular discharges, dyspnea and sometimes diarrhoea [1]. Severe BRDC including BPIV3 infections can even lead to cardiac complications [2]. Unfavourable environmental factors such as low temperature and inadequate nutrition may influence the course of the disease in cattle [3]. BPIV3 belongs to genus Respirovirus, subfamily Paramyxovirinae and family Paramyxoviridae. The genome of the virus consists of a single - stranded, non - segmented RNA molecule and a helicoidal capsid surrounded with an outer envelope [1,4]. Hemagglutinin-neuraminidase (HN) antigen of the outer envelope of parainfluenza virus type 3 represents a tetramer consisting of a two disulfide linked dimer. This is a multifunctional molecule with three different and crucial activities for cell infection: receptor binding activity, neuraminidase activity and fusion promotion activity [5]. Three genotypes: A (BPIV3a), B (BPIV3b) and C (BPIV3c) have been described, based on genetic and phylogenetic analysis [6]. Previously, the complete genome analysis of the BPIV3 isolates from Australia and America indicated that their viral strains were classified into two distinct genotypes, BPIV3 genotype A and BPIV3 genotype B. Recently, four Chinese isolates of BPIV3 were found to be distinct from other reported BPIV3 strains and classified as genotype C [1]. Currently several traditional and molecular laboratory methods are in use for diagnosis of BPIV3. The gold standard in the laboratory diagnosis of BPIV3 is the virus isolation method followed by virus-neutralization test (VN test). Some other tests can also be used, such as hemagglutination test (HA test), hemagglutination - inhibition test (HI test), ELISA and direct or indirect immunofluorescence [7]. The molecular methods often used for diagnosis of BPIV3 infection are RT-PCR and real-time RT-PCR [8]. The aim of our study was to investigate if BPIV3 was present as an etiological agent of respiratory disorders in cattle in Serbia and to characterize (if present) the virus isolate.

\section{MATERIALS AND METHODS}

\section{Samples}

In total, 119 samples of nasal swabs were collected from calves and cows with severe respiratory infection from 20 herds of intensive and small backyard livestock productions from different areas of the Republic of Serbia (mainly central parts of Serbia - surroundings of City of Belgrade (Municipalities of Obrenovac and 
Mladenovac), cities of Jagodina and Kruševac and Municipality of Svilajnac). Immediately after swabbing the nasal cavity of animals, the cotton part of the swabs were cut and immersed into $1.5 \mathrm{~mL}$ of PBS 7.2 supplemented with antibiotics and chilled on ice during transport to the laboratory. In the laboratory, the nasal swabs samples in PBS were vortexed vigorously multiple times and used immediately for testing or freezed on $-20^{\circ} \mathrm{C}$ pending testing.

\section{Isolation of virus in cell culture}

For virus isolation, Madin-Darby bovine kidney - MDBK cell line (ATCC CCL-22, IZSBS, Brescia, Italy) was used. As the positive control, SF4 strain of BPIV3 (ATCCVR 281, American Bioresearch, USA) with a titre of $6 \log _{10} \mathrm{TCID}_{50} / \mathrm{ml}$ was used during the examinations. All samples of nasal swabs, prepared as previously described, were individually inoculated into 24 hours old and $80 \%$ confluent monolayer of MDBK cell line in 24-well microtiter plates. Each well, after the aspiration of growing media, was inoculated with $100 \mu \mathrm{l}$ of sample and incubated for $1 \mathrm{~h}$ at $37^{\circ} \mathrm{C}$ in an environment with $5 \% \mathrm{CO}_{2}$. After one hour, 500 $\mu$ l of minimum essential medium (MEM, Biochrom, Germany) supplemented with $2 \%$ fetal calf serum (PAA, Austria) was added. Plates were then incubated in the above mentioned conditions and observed daily for the appearance of cytopathic effect of virus (CPE). If CPE was not observed after 7 days, the plates with the inoculated cell cultures were frozen and thawed three times and passaged for two more times at five days intervals. If CPE appeared in the monolayer of MDBK cells, the cells were frozen and the virus isolates were further identified [9].

\section{Virus - neutralization test (VN - test)}

Twofold serial dilutions of heat - inactivated specific immune serum against BPIV3 (Scientific Institute of Veterinary Medicine of Serbia, Belgrade, Serbia; titer 128) were incubated for $1 \mathrm{~h}$ at $37^{\circ} \mathrm{C}$ with equal volumes of $100 \mathrm{TCID}_{/ 50}$ of the previously titrated supernatants from inoculated MDBK cells with CPE in the wells of microplates. SF4 strain of BPIV3 (in working dilution of 100 TCID $_{/ 50}$ ) served as a positive control in the assay. After the end of the incubation period, the aliquots prepared from the mixture of supernatants and specific immune sera were transferred to the MDBK cells monolayers in 96 -well microplates and incubated for three days at $37^{\circ} \mathrm{C}$ [10]. The absence of CPE was considered as a positive result of virus isolate neutralization.

\section{RT-PCR detection}

The extraction of viral RNA from the nasal swab samples, prepared as previously described, was done using Pure Link RNA Mini Kit (Ambion, Life Technology, USA) according tothemanufacturer'sinstruction. Primersforthespecificpartof hemagglutininneuraminidase $(\mathrm{HN})$ gene of BPIV3 were used for one step reverse transcription polymerase chain reaction (RT-PCR) (forward 5'GAATGACTCATGATAGAGGTA3' and reverse 5'AGGACAACCAGTTGTAT'TACAT3') [11]. For amplification, One- 
Step RT-PCR kit (Qiagen, Germany) was used according to the manufacturer's instructions. Briefly, the reaction was performed in a total volume of $25 \mu \mathrm{l}$ as follows: $12 \mu \mathrm{l}$ of nuclease free water, $5 \mu \mathrm{l}$ of $5 \mathrm{x}$ PCR buffer, $1 \mu \mathrm{l}$ of dNTP mix (containing $10 \mathrm{mM}$ of each dNTP), $1 \mu \mathrm{l}$ of $20 \mu \mathrm{M}$ solution of each primer, $1 \mu \mathrm{l}$ of one step RTPCR enzyme mix and $5 \mu$ of RNA template. Virus positive controls and negative controls were also performed for each reaction. RT-PCR protocol comprised reverse transcription at $50^{\circ} \mathrm{C}$ for 30 minute followed with initial denaturation at $93^{\circ} \mathrm{C}$ for 3 minutes. After this step, PCR consisted of 35 repeated cycles of denaturation at $94^{\circ} \mathrm{C}$ for $45 \mathrm{sec}$, annealing at $49^{\circ} \mathrm{C}$ for $45 \mathrm{sec}$ and elongation at $72^{\circ} \mathrm{C}$ for $60 \mathrm{sec}$. The process was finalised with a final elongation at $72^{\circ} \mathrm{C}$ for 10 minutes. The presence of specific 647bp product of BPIV3 detected by agarose gel electrophoresis was considered as a positive result [11].

\section{BPIV3 HN gene direct sequencing}

PCR products of partial BPIV3 HN gene nucleotide sequences were purified with QIA quick Purification Kit (Qiagen, Valencia, CA, USA). The purified PCR products were subsequently sequenced with Big Dye Terminator Cycle Sequencing Kit (PE Applied Biosystems, Foster City, CA, USA) using PCR primers as sequencing primers. Direct sequencing of BPIV3 isolates nucleic acid sequence was performed by Sanger sequencing method. Cycle sequencing protocol comprised of initial denaturation at 96 ${ }^{\circ} \mathrm{C}$ for 2 minutes, followed by 40 repeated cycles of denaturation at $96{ }^{\circ} \mathrm{C}$ for $10 \mathrm{sec}$, annealing at $50{ }^{\circ} \mathrm{C}$ for $5 \mathrm{sec}$ and elongation at $60{ }^{\circ} \mathrm{C}$ for 4 minutes. The sequencing products were purified by isopropanol and denatured at $95^{\circ} \mathrm{C}$ for 2 minutes. Sequencing reactions were analysed on the ABI Prism 310 Genetic Analyser (Applied Biosystems, USA). The obtained nucleotide sequences were aligned and compared with documented virus sequences available in the GenBank database using BLAST tool (http://www.ncbi.nlm.nih.gov/BLAST). Evolutionary analyses were conducted in MEGA 6 software [12]. The phylogenetic tree of BPIV3 virus isolates from this study and strains obtained from NCBI GenBank was constructed using NeighborJoining algorithm with 1000 bootstrap replicates. The evolutionary distance computed using Maximum Composite Likelihood method [13].

\section{RESULTS}

\section{Virus isolation}

The cytopathic effect was observed $48 \mathrm{~h}-72 \mathrm{~h}$ after inoculation into the MDBK cell line for eight out of 119 tested (8/119; 6.7\%) nasal swab samples. All isolates were confirmed as BPIV3 by virus neutralization test. Six out of 8 BPIV3 isolates were obtained from 3 to 4 month old calves and two isolates were from cows. All virus positive animals had a severe respiratory infection at the time of sampling. Details like virus isolates names, origin, time of sampling and location of positive materials are 
shown in Table 1. The area from where the isolates were obtained has a diameter of approximately $200 \mathrm{~km}$ in the central part of the Republic of Serbia.

Table 1. Details of the isolated BPIV3 strains

\begin{tabular}{lllll}
\hline BPIV3 isolate & $\begin{array}{c}\text { GenBank } \\
\text { Accession } \\
\text { No }\end{array}$ & $\begin{array}{c}\text { Date of } \\
\text { isolation }\end{array}$ & Origin & \multicolumn{1}{c}{$\begin{array}{c}\text { Location } \\
\text { (area of municipality, city) }\end{array}$} \\
\hline BPIV3-SRB001 & KX579933 & 13 March 2013 & 4 months old calf & Svilajnac \\
\hline BPIV3-SRB002 & KX579934 & 22 March 2013 & 4 months old calf & Jagodina \\
BPIV3-SRB003 & KX579935 & 13 March 2013 & 4 months old calf & Svilajnac \\
BPIV3-SRB004 & KX579936 & 22 March 2013 & 4 months old calf & City of Belgrade (Mladenovac) \\
BPIV3-SRB005 & KX579937 & 03 May 2013 & 3 months old calf & City of Belgrade (Obrenovac) \\
\hline BPIV3-SRB006 & KX579938 & 03 May 2013 & 3 months old calf & City of Belgrade (Obrenovac) \\
\hline BPIV3-SRB062 & KX579939 & 18 April 2014 & Cow & Kruševac \\
\hline BPIV3-SRB100 & KX579940 & 18 April 2014 & Cow & Kruševac \\
\hline
\end{tabular}

\section{RT-PCR}

All samples of bovine nasal swabs were also examined for the presence of BPIV3 using RT-PCR methods with primers for the specific part of the HN gene. The presence of BPIV3 was detected in eight samples $(8 / 119 ; 6.7 \%)$ that were also positive by virus isolation. This result additionally confirms the result of virus isolation and the presence of BPIV3 in cattle population in the Republic of Serbia.

\section{BPIV3 isolates phylogenetic analysis}

The phylogenetic analysis of the HN gene nucleotide sequences showed that all eight analysed BPIV3 isolates from Serbia detected in this study belong to genotype $\mathrm{C}$ of BPIV3 (BPIV3c). Nucleotide sequences of 577 bp long HN gene of all 8 BPIV3 isolates were submitted to the NCBI GenBank (Accession No: KX579933 - KX579940) (Table 1; Fig. 1). Regarding the differences that were found between Serbian isolates, they can be separated in one distinct cluster with three different branches (Fig. 1). The HN gene nucleotide sequences of isolates BPIV3-SRB004, BPIV3-SRB005 and BPIV3-SRB006 are 100\% similar to each other and branched into one branch. Isolates BPIV3-SRB001, BPIV3-SRB002 and BPIV3-SRB003 belonging to the second branch were $100 \%$ and $99.8 \%$ similar to each other and $99.7 \%$ to $99.8 \%$ similar to the strains from the first branch. Isolates BPIV3-SRB062 and BPIV3-SRB100 belonging to the third branch were $99.7 \%$ similar to each other and $98.4 \%$ and $98.1 \%$ similar to the isolates from the first and the second branch, respectively. Serbian isolates branched together with Chinese, South Korean, Japanese and some American BPIV3 strains. The similarities found between Serbian BPIV3 isolates and Chinese BPIV3c isolates SD0805, SD0809 and SD0835 were from $97.92 \%$ to $99.7 \%$, and similarities found 
between Serbian BPIV3 isolates and South Korean (12Q061), Japanese (HS9) and American (TVMDL16 and TVMDL20) BPIV3c strains were from 97.4\% to $98.96 \%$ and from $97.1 \%$ to $98.8 \%$ respectively. Serbian BPIV3 isolates were only $79.9 \%$ to $81.3 \%$ and $81.3 \%$ to $82.3 \%$ similar to American (TVMDL15 and TVMDL17) and Australian (Q5592) BPIV3 genotype B strains respectively, and between 79.3\% and $81.9 \%$ similar to the genotype A BPIV3 strains published in GenBank. The similarities found between Serbian BPIV3 isolates and human BPIV3 strains were just from $76.2 \%$ to $77.3 \%$ (Fig. 1 ).

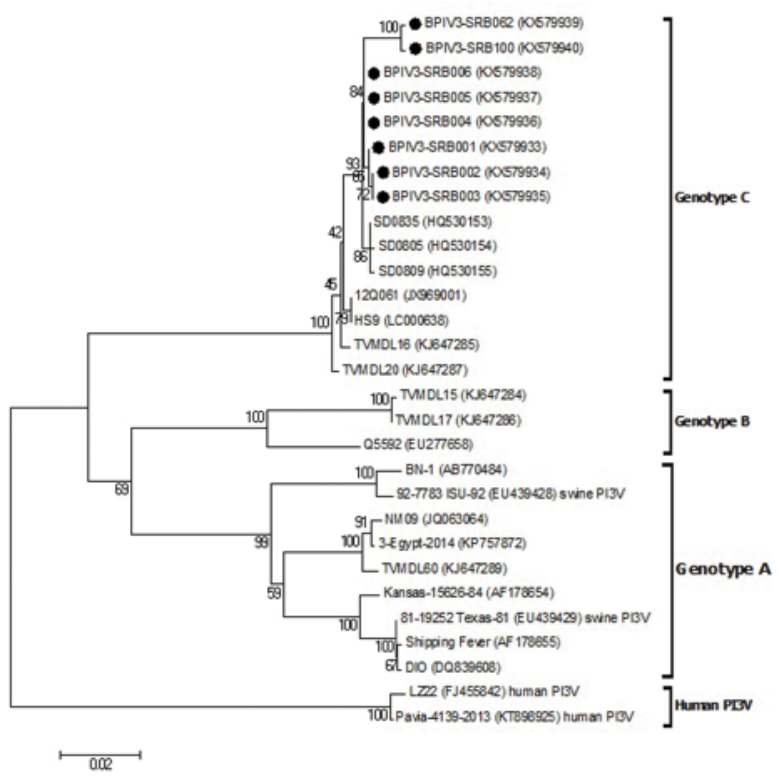

Figure 1. Phylogenetic tree constructed from 577 long $\mathrm{HN}$ gene nucleotide sequences of 8 Serbian BPIV3 isolates (NCBI GenBank Accession No: KX579933 - KX579940; marked with black circle) and 21 nucleotide sequences of bovine, swine and human PIV3 isolates and reference strains obtained from NCBI GenBank. The tree was constructed using neighbour - joining method based on bootstrap of 1000 replicates (using MEGA version 6). The evolutionary distance computed using Maximum Composite Likelihood method. The scale bar indicates the branch length based on the number of nucleotide substitutions per site.

\section{DISCUSSION}

The presence of BPIV3 in Serbia was already known through routine diagnostic testing, for many years in the past, but the virus isolates were never fully characterized. In this study we confirmed that BPIV3 is present as an etiological agent of respiratory disorders in cattle in Serbia. Out of 119 tested nasal swabs from animals with severe respiratory infection, reared in both intensive and backyards livestock productions, BPIV3 was detected and confirmed, by both virus isolation and RT-PCR method, in nasal swabs of eight animals $(8 / 119)$ or $6.7 \%$ of tested samples. The samples were 
collected from the territory of the central part of Serbia (diameter of approximately $200 \mathrm{~km}$ between the outermost cases), and the distribution of BPIV3 positive animals confirmed that this virus was present on the whole tested area, and probably all over the country.

In order to detect BPIV3 presence in nasal swabs of animals with acute and severe respiratory infection, the virus isolation on MDBK cell line was used. The gold standard in laboratory diagnosis of BPIV3 is still the method of virus isolation in cell lines followed by virus neutralization test, and MDBK cell line is a very sensitive cell culture for propagation of BPIV3 [1,14]. In our study, cytopathic effects on MDBK cells were observed 48 hours and 72 hours after inoculation, in eight inoculated nasal swabs. The confirmation of eight isolated BPIV3 was done by the virus neutralization test. Similar studies were also described in the literature. Gafer and co-authors [15] isolated three strains of BPIV3 from 205 nasal swabs of sheep and goats collected in seven different regions in Egypt, by using the same methodology as we did in the present study. They also performed the virus isolation on MDBK cell line and confirmed the isolated strains by virus neutralization test and RT-PCR.

Having in mind that the $\mathrm{HN}$ protein of the outer envelope of the virus plays a crucial role for receptor binding activity, neuraminidase activity and fusion promotion activity, phylogenetic analysis of nucleotide sequences of a part of the HN gene was performed. The results of phylogenetic analysis of the $577 \mathrm{bp}$ long nucleotide sequences of the HN gene showed that all eight Serbian BPIV3 isolates obtained in this study belonged to the genotype $\mathrm{C}$ of BPIV3 (BPIV3c). The BPIV3c strains were recently discovered in China, when Zhu and collaborators [11] found that some of the detected and phylogenetically analysed BPIV3 strains isolated during 2008 were distinct from previously characterized virus strains. Phylogenetic analysis of partial $\mathrm{HN}$ gene for four isolates and the complete genome for the SD0835 isolate implicated that the four Chinese BPIV3 strains were distinct from the previously reported genotype A (BPIV3a) and genotype B (BPIV3b) strains. Thus the authors suggested that those strains should be considered as genotype C BPIV3 strains (BPIV3c) [11]. A similar strategy for detection and molecular characterization of BPIV3 was reported by a number of authors $[1,3,4,6,11,15,16]$.

Previously Horwood and co-authors [16] analysed the nucleotide sequences, based on matrix (M) gene, of seven isolated Australian BPIV3 strains. The nucleotide sequences of three isolates were highly similar with the nucleotide sequence of reference BPIV3a strain Kansas/15626/84 (93\%), while the nucleotide sequences of other four isolates, including the representative isolate Q5592, showed less similarity to Kansas/15626/84 BPIV3a strain $(83.9 \%-84.5 \%)$. The authors suggested classification of those BPIV3 isolates to a new genotype, namely genotype B (BPIV3b). Maidana and collaborators [6] isolated parainfluenza virus type 3 (PIV3) from dairy buffaloes (Bubalus bubalis) naturally affected with respiratory and reproductive clinical conditions in Argentina, and performed nucleotide and amino acid phylogenetic analysis of partial $\mathrm{M}$ gene sequences. Results showed that Buffalo isolates were similar to genotype B (BPIV3b), 
while the other six bovine BPIV3 isolates from Argentina included in the study were similar to genotypes A (BPIV3a) and C (BPIV3c). Oem and collaborators [3] isolated BPIV3 from bovine nasal swabs in South Korea. All animals (Korean native cattle) presented clinical signs of mild pneumonia. The complete genome of the isolated 12Q061 strain of BPIV3 was sequenced and found to be closely related to the Chinese strain SD0835, so it was classified as genotype C (BPIV-3c). Also, Wen and co-workers [1] isolated BPIV3 named as NM09 from bovine nasal swab in China. The NM09 isolate was characterized by RT-PCR and nucleotide sequence analysis. Nucleotide phylogenetic analysis of $\mathrm{M}$ and $\mathrm{HN}$ gene demonstrated that this NM09 isolate belonged to BPIV3 genotype A. Similarly Ohkura and collaborators [17] reported complete genome sequences of the BPIV3 BN-1 strain, isolated in Japan that was phylogenetically analysed and classified into genotype A of BPIV3.

All BPIV3 isolates phylogenetically analysed in this study were classified as genotype $C$ strains. The analysed isolates were obtained from animals widely distributed in different parts of central Serbia with a distance of about $200 \mathrm{~km}$ between the outermost cases. In addition, BPIV3 were isolated from animals from commercial cattle farms as well as from backyard animals (one or a few animals per household). This result strongly indicated that BPIV3c strains were probably widely distributed in the whole country, and that probably the BPIV3c strains were the main virus genotype present in Serbia in this moment. Regarding the differences found between partial HN gene nucleotide sequences of Serbian isolates obtained in this study, they can be separated in one distinct cluster with three different branches, however isolates from these branches are very similar to each other ( $98.1 \%$ to $99.8 \%$ ). It should be consider that the analysis was done on only 577 bp long nucleotide sequences. Also, it must be emphasized that there is a very limited number of BPIV3 nucleotide sequences available in GenBank. Just a few whole genome and HN gene nucleotide sequences of BPIV3 were published in NCBI GenBank. Those viruses were from China, South Korea, Japan and USA. There is no whole genome or $\mathrm{HN}$ gene nucleotide sequence of BPIV3 from Europe that are published in NCBI GenBank. So, it is very difficult to discuss the possible similarities and differences of Serbian BPIV3c isolates in their geographic surroundings. The Serbian BPIV3c isolates branched together with Chinese, South Korean, Japanese and some American BPIV3 strains. Serbian BPIV3c isolates were the most similar to Chinese BPIV3c isolates SD0805, SD0809 and SD0835 (from 97.92\% to 99.7\%), and then to South Korean (12Q061), Japanese (HS9) and American (TVMDL16 and TVMDL20) BPIV3c strains (from 97.1\% to 98.8\%). We could not find any direct connection either by trade of animals or by any kind of contacts in the near past that could be the reason of virus transmission and consequently the similarity between Serbian BPIV3 strains on one side, and Chinese, South Korean and American BPIV3 strains on the other side, especially without data from other European countries, so it could be assumed that genotype C BPIV3 strains were present in Republic of Serbia for a long time. 
Serbian BPIV3c isolates were found to be very distinct from American (TVMDL15 and TVMDL17) and Australian (Q5592) BPIV3 genotype B strains (only 79.9\% to $82.3 \%$ similarity), as well as from the genotype A BPIV3 strains from different counties published in GenBank (similarity from 79.3\% to 81.9\%).

We could stress that virus isolation and RT-PCR detection with consecutive molecular typing are very suitable methods for BPIV3 detection and characterization. Due to the results from this study and considering that the presented data represents one of the first reports of the molecular detection and phylogenetic analysis of BPIV3 isolates in the Republic of Serbia, more data and research is needed on virus isolation and molecular characterization of BPIV3 from cattle in north and south parts of Serbia to define if BPIV3 genotype A or B strains are present in the country.

\section{Acknowledgments}

This study was supported by the Ministry of Education, Science and Technological Development of the Republic of Serbia (grant no. TR31008, TR31084, and III173024).

\section{Authors' contributions}

$\mathrm{LjV}, \mathrm{AK}, \mathrm{MS}$, TP, JN, MS carried out the molecular genetic studies, participated in the sequence alignment and drafted the manuscript. NM, AZ, MM, DK participated in the sequence alignment. VM, JMZ,RM participated in the design of the study. All authors read and approved the final manuscript.

\section{Declaration of conflicting interests}

The author(s) declared no potential conflicts of interest with respect to the research, authorship, and/or publication of this article.

\section{REFERENCES}

1. Wen YJ, Shi XC, Wang FX, Wang W, Zhang SQ, Li G, Chen LZ, Cheng SP, Wu H: Phylogenetic analysis of the bovine parainfluenza virus type 3 from cattle herds revealing the existence of a genotype A strain in China. Virus Genes 2012, 3:542-547.

2. Hanadan B, Kirbas A, Dorman E, Timurkan MO, Kandemir FM, Alkan O: Cardiac troponin-I concentration in weaned calves with bovine respiratory disease. Acta VeterinariaBeograd 2015, 65 (4):454-462

3. Oem JK, Lee EY, Lee KK, Kim SH, Lee MH, Hyun BH: Molecular characterization of a Korean bovine parainfluenza virus type 3 isolate. Veterinary Microbiology 2013, 162:224227. 
4. Veljović Lj, Knežević A, Milić N, Nišavić J: The application of molecular methods in the identification of isolated strains of parainfluenza 3 virus of cattle. Archive of biological science 2014, 66:491-496.

5. Nišavić J, Milić N: Examination of the activity of glycoprotein $\mathrm{HN}$ and $\mathrm{F}$ antigens of outer envelope of the parainfluenza virus type 3 by using fusional, hemolytic and hemagglutinating test, in vitro. Acta veterinaria 2006, 56:431-436.

6. Maidana S, Lomonaco P, Combessies G, Craig M, Diodati J, Rodrigez D, Parreno V, Zabal O: Isolation and characterization of bovine parainfluenza virus type 3 from water buffaloes (Bubalus bubalis) in Argentina. Veterinary Research 2012, 83:1-9.

7. Yong Yang, Feng - Xue Wang, Na Sun, Li Cao, Shu - Qin Zhang, Hong- Wei Zhu, Li Guo, Shi - Peng Cheng, Yong - Jun Wen: Development and evaluation of two truncated recombinant NP antigen - based indirect ELISAs for detection of bovine parainfluenza virus type 3 antibodies in cattle. Journal of virological methods 2015, 222:47-54.

8. Lyon M, Leroux C, Chaestag T, Patet J, Mornex JF: Presence of a unique parainfluenza virus 3 strain identified by RT-PCR in visna-maedi virus infected sheep. Veterinary Microbiology 1997, 51:95-104.

9. Nišavić J, Milić N, Knežević A: Laboratorijska dijagnostika virusnih infekcija. In: Izolacija virusa u kulturi ćelija. Beograd, Srbija: Naučna KMD; 2013, 34-36.

10. Jian - Le Ren, Yuan - Mao Zhu, Yue - Hui Zhou, Chuang Lv, Hao Yan, Lei Ma, Hong - Fei Shi, Fei Xue: Identification of three antigen epitopes on the nucleocapsid protein of the genotype $C$ of bovine parainfluenza virus type 3. Veterinary Microbiology 2015, 178:61-69.

11. Zhu YM, Shi HF, Gao YR, Xin JQ, Liu NH, Xiang WH, Ren XG, Feng JK, Zhao LP, Xue F: Isolation and genetic characterization of bovine parainfluenza virus type 3 from cattle in China. Veterinary Microbiology 2011, 149:446-451.

12. Tamura K., Nei M., and Kumar S.: Prospects for inferring very large phylogenies by using the neighbor-joining method. Proceedings of the National Academy of Sciences (USA) 2004, 101:11030-11035.

13. Tamura K., Stecher G., Peterson D., Filipski A., and Kumar S.: MEGA6: Molecular Evolutionary Genetics Analysis version 6.0. Molecular Biology and Evolution 2013, 30:2725-2729.

14. Conceciao MM, Tonso A, Freitas CB, Pereira CA: Viral antigen production in cell cultures on microcarriers bovine parainfluenza 3 virus and MDBK cells. Vaccine 2007, 25:77857795.

15. Gafer JAM, Hussein A,Reda IM: Isolation and characterization of PI3 virus from sheep and goat. International Journal of Virology 2009, 1:28-35.

16. Horwood PF, Gravel JL, Mahony TJ: Identification of two distinct bovine parainfluenza virus type 3 genotypes. Journal of General Virology 2008, 89:1643-1648.

17. Ohkura T, Kokuho T, Konishi M, Kameyama K, Takeuchi K: Compete genome sequences of bovine parainfluenza virus type 3 strain $\mathrm{BN}-1$ and vaccine strain $\mathrm{BN}-\mathrm{CE}$. Genome Announcement 2013, 1:1. 


\section{IZOLACIJA I MOLEKULARNA DETEKCIJA PARAINFLUENCA 3 VIRUSA KOD GOVEDA U SRBIJI}

VELJOVIĆ Ljubiša, KNEŽEVIĆ Aleksandra, MILIĆ Nenad, KRNJAIĆ Dejan, MIKOVIĆ Radoš; ZORIĆ Andrea, MARKOVIĆ Maja MILIĆEVIĆ Vesna, STAMENKOVIĆ Miodrag, STANOJEVIĆ Maja, MAKSIMOVIĆ-ZORIĆ Jelena, PETROVIĆ Tamaš, NIŠAVIĆ Jakov

Ukupno je ispitano 119 uzoraka nosnih briseva goveda na prisustvo parainfluenca 3 virusa goveda (bovine parainfluenza virus type, eng. - 3 BPIV3). Iz svih uzoraka nosnih briseva je vršena izolacija virusa na ćelijskoj liniji MDBK. Pojava citopatogenog efekta na kulturi ćelija, nakon 48h, odnosno $72 \mathrm{~h}$, utvrđena je kod osam uzoraka nosnih briseva $(8 / 119 ; 6.7 \%)$. Identifikacija izolovanih sojeva BPIV3 je izvršena primenom virus neutralizacionog testa. Dodatno, svi uzorci nosnih briseva goveda su ispitani na prisustvo BPIV3 i primenom metode RT-PCR uz korišćenje prajmera specifičnih za deo HN gena virusa. Prisustvo virusne nukleinske kiseline je utvrđeno kod osam uzoraka nosnih briseva (8/119; 6.7\%), koji su bili pozitivni i na izolaciji virusa. Molekularna karakterizacija zasnovana na sekvenciranju dela HN gena izolata BPIV3 iz Srbije je potvrdila da svi pripadaju genotipu C BPIV3 (BPIV3c). Oni su se u filogenetskom stablu granali u tri različite grane koje su međusobno veoma slične (98.1\% do 99.8\%). Izolati BPIV3 iz Srbije su pokazali visok stepen sličnosti nukleotidnih sekvenci sa BPIV3c sojevima SD0805, SD0809 i SD0835 iz Kine (97.92\% do 99.7\%), odnosno sa BPIV3c sojevima 12Q061 iz Južne Koreje, HS9 iz Japana i TVMDL16 i TVMDL20 iz Amerike (sličnost od 97.1\% do 98.8\%), kao i različitosti u odnosu na nukleotidne sekvence sojeva TVMDL15 i TVMDL17 izolovanih u Americi i soja Q5592 izolovanog u Australiji, a koji su pripadali genotipu B BPIV3 (sličnost od 79.9\% do 82.3\%). Slična razlika je utvrđena i sa nukleotidnim sekvencama sojeva virusa, poreklom iz različitih država, svrstanih u genotip A BPIV3, a objavljenih u genskoj bazi podataka (NCBI GenBank). 